BIOKEMISTRI 17(2):165-170 (Dec 2005)

Available online at http://www.bioline.org.br/bk.

Abstracted online at www.ajol.info/journals/biokem
An international journal published by the

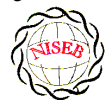

OVigerian Society for E̊xperimental \&iology

Printed in Nigeria

\title{
Effect of bonny light crude oil on some haematological parameters of guinea pigs
}

\author{
Daniel U. OWU ${ }^{1}$, Uwana B. UDOETE ${ }^{2}$, Nyoh AZAH ${ }^{1}$ and Eyong U. EYONG ${ }^{3 *}$
}

Departments of ${ }^{1}$ Physiology and ${ }^{3}$ Biochemistry, College of Medical Sciences, University of Calabar, Calabar, Nigeria

2. Department of Science Technology, School of Applied Science, Akwa Ibom State Polytechnic, Ikot Ekpene, Akwa Ibom State, Nigeria

Received 10 September 2004

MS/No BKM/2004/022, (C) 2005 Nigerian Society for Experimental Biology. All rights reserved.

\begin{abstract}
The effect of Bonny light crude oil on some haematological parameters (red cell count, white cell count, platelet count, packed cell volume and hemoglobin concentration) were studied in guinea pigs. The two experimental groups were gavaged with $4 \mathrm{ml} / \mathrm{kg}$ and $6 \mathrm{ml} / \mathrm{kg}$ respectively for seven days while the control group was gavaged with olive oil $(6 \mathrm{ml} / \mathrm{kg})$ for seven days. The red cell count in the $4 \mathrm{ml} / \mathrm{Kg}$ group was significantly lower $(\mathrm{P}<0.05)$ when compared with control and $6 \mathrm{ml} / \mathrm{Kg}$ group. The platelet count showed statistically significant difference $(\mathrm{P}<0.05)$ when the two test groups were compared with the control and also when compared to each other $(\mathrm{P}<0.05)$. Haemoglobin concentrations were significantly increased $(\mathrm{P}<0.05)$ in high dose group compared with low dose group and control. There were no significant differences in haemoglobin concentrations of low dose group when compared with control. The results indicate that gavaging of guinea pigs with Bonny light crude oil cause changes in some hematological parameters due to the injurious effect of the toxic components of the crude oil.
\end{abstract}

Key words: Bonny light crude oil, hematological parameters, guinea pigs

*Author to whom all correspondence should be addressed.

E-mail: eubana@yahoo.com,d_owu@yahoo.com, Tel: +234 8037236 701, +234 8055380694 


\section{INTRODUCTION}

Crude oil has been described as a complex mixture of over 6000 potentially different hydrocarbons and metals ${ }^{1}$ and the chemical composition varies in different geologic formation $^{2}$. The major fraction of crude oils is polycyclic aromatic hydrocarbon e.g. naphthalene, anthracene phenanthrene and benzo[a]pyrene ${ }^{3}$. The Nigerian Bonny crude oils are classified as light crude oils, with hydrocarbons accounting for up to $45 \%$ of the total hydrocarbons ${ }^{4}$. Aromatic hydrocarbons are relatively soluble in water ${ }^{5}$ and have the high adverse effect on the body than the heavier, less water-soluble crude oils ${ }^{4}$.

Beyond the normal environmental and ecological shocks of normal oil activities, oil operations have had other far reading implication and pathological effects, especially on the oil province of Nigeria the Niger Delta ${ }^{6}$. The cells of many species including man are continually exposed to industrial pollutants and other compounds ${ }^{7}$. The land, air and water pollution resulting from gas flares or common oil blowouts and spillage are regular occurrence in the Niger Delta ${ }^{6}$.

Previous studies have shown that petroleum hydrocarbons can have both lethal and sublethal effects on a wide range of marine organisms. The sublethal effects include: interference with chemotactic response in bacteria resulting in inhibition of biodegradation in sea water ${ }^{8}$, depressed photosynthetic rate in algae $^{9}$, interference with reproduction in sanddolars $^{9}$ and reduced resistance to environmental stress in crabs $^{10}$. Eyong ${ }^{11}$ has also reported haematotoxic effect of crude oil in rats following ingestion of Bonny light crude oil. Many shellfish including clams and oysters have been shown to accumulate these hydrocarbons and hence are able to transfer these compounds to higher trophic levels including man ${ }^{11,12}$. Apart from reaching man through the food chain (bioaccumulation), crude petroleum is taken orally in many oil-producing communities for the "laxative effect" or as a general antidote "against poisonous substances" and witchcraft ${ }^{4}$, 13

It has been reported that hydrocarbon compounds, which are the major components of crude oil are metabolically transformed by cytochrome P-450-linked polysubstrate monooxygenase system to highly reactive and carcinogenic compounds ${ }^{14,15}$. The metabolites of benzene and polycyclic aromatic hydrocarbon have been shown to be very potent carcinogens $^{16-18}$. The present study, investigates the effect of Bonny light crude oil on some hematological parameters in guinea pigs.

\section{MATERIALS AND METHODS}

\section{Source of crude oil}

Crude oil (Bonny light) used in this study was obtained from Shell Petroleum Development Company, Port Harcourt, River State, with permission from the Department of Petroleum Resources (DPR), NNPC, Lagos, Nigeria.

\section{Experimental Animals}

Eighteen Guinea pigs weighing between 400$550 \mathrm{~g}$ were obtained from the animal house of the College of Medical Sciences, University of Calabar, Calabar, Nigeria and were randomly placed into three groups of six animals each, one control and two test groups. The animals were housed individually in stainless steel meshbottomed cages kept in the animal room at ambient temperature of $29 \pm 2{ }^{0} \mathrm{C}, 12 \mathrm{~h}$ light, $12 \mathrm{~h}$ dark cycle and were acclimatized to housing condition for two week before the commencement of the experiment. Water and food were provided ad libitum for the animals.

\section{Administration of Crude Oil}

The two test groups of animals received by gavage for seven days freshly prepared Bonny light crude oil dissolved in olive oil at doses of $4 \mathrm{ml} / \mathrm{kg}$ (group I) and $6 \mathrm{ml} / \mathrm{kg}$ (group 2) while the last group received olive oil at $4 \mathrm{ml} / \mathrm{kg}$ as control. Administration was done between $08 \mathrm{hrs}$ and 09hrs GMT each day. These doses were based on that used by the local population in folkloric medicine.

\section{Collection of Blood Samples}

The animals were anesthetized with chloroform on the morning of the $8^{\text {th }}$ day and blood was collected from the abdominal aorta and immediately transferred into anticoagulant bottles containing EDTA. 


\section{Analysis of haematological parameters}

Red blood cells and white blood cells and platelets were estimated by the haemocytometer method under light microscope using the improved Neuber chamber method of Dacie and Lewis ${ }^{19}$. Packed cell volume and haemoglobin concentration were determined using the methods of Alexander and Grifiths ${ }^{20-21}$. The $\mathrm{MCV}$ and $\mathrm{MCH}$ were calculated from the standard relationship of haematocrit and red cell count.

\section{Statistical Analysis}

Data from the studies were expressed as mean \pm standard error of mean (SEM). Multiple comparisons of means were carried out using one-way analysis of variance followed by student's t-test for significant values and $\mathrm{P}<0.05$ was considered statistically significant.

\section{RESULTS}

The red cell counts in guinea pigs gavaged with crude oil are shown in Table 1 . The results revealed that group I had a significantly $(\mathrm{P}<0.05)$ low red cell count when compared with control and group II. However, there was no significant difference between group II and control.

The results presented in table I also show white blood cell count values of the control, groups I and II animals. Group II had a significantly $(\mathrm{P}<0.05)$ higher count when compared with the control. The two test groups were significantly $(\mathrm{P}<0.05)$ different from each other with group I having a lower value. There was however no significant difference between group I and control.

The platelet counts of both control and experimental groups are also presented in the Table. Groups I and II had significantly $(\mathrm{P}<0.05)$ higher platelet counts when compared with control. The platelet count of group II was also significantly $(\mathrm{P}<0.05)$ higher than that of group I. The haematocrit values for all the groups is presented in the Table and shows that Group I animals had a significantly $(\mathrm{P}<0.05)$ lower values of haematocrit when compared with the control value. There was no significant difference in haematocrit values between group II and Group I. The value of haemoglobin concentration of the group II was significantly $(\mathrm{P}<0.05)$ higher than that of group I and control group. There was however no significant difference in haemoglobin concentration when group I was compared with the control group.

The values for mean corpuscular volume (MCV) and mean corpuscular haemoglobin $(\mathrm{MCH})$ of control and two experimental groups are presented in the Table. Group I had a significantly $(\mathrm{P}<0.05)$ higher $\mathrm{MCV}$ compared with the control while group II was not significantly different from the control. The MCV value of group II animals was significantly $(\mathrm{P}<0.05)$ lower in when compared with group I. There was no statistically significant difference between the MCV of group II and control animals. The $\mathrm{MCH}$ in group II was significantly $(\mathrm{P}<0.05)$ higher compared to control. There was no significant difference in $\mathrm{MCH}$ when group I was compared with control and group II.

Table 1: Various haematological parameters in Guinea pig treated with Bonny light crude oil

\begin{tabular}{|c|c|c|c|c|c|c|c|}
\hline Parameters & $\begin{array}{l}\text { PCV } \\
(\%)\end{array}$ & $\begin{array}{l}\mathrm{RBC} \\
\left(\times 10^{12} / \mathrm{L}\right)\end{array}$ & $\begin{array}{l}\text { WBC } \\
\left(x_{10} / L\right)\end{array}$ & $\begin{array}{l}\mathrm{HB} \\
(\mathrm{g} / \mathrm{L})\end{array}$ & $\begin{array}{l}\text { MCV } \\
\text { (fL) }\end{array}$ & $\begin{array}{l}\text { MCH } \\
\text { (pg) }\end{array}$ & $\begin{array}{l}\text { Platelets } \\
\left(\mathbf{x 1 0}^{9} / \mathrm{L}\right)\end{array}$ \\
\hline Control & $\begin{array}{l}45.67 \\
\pm 0.22\end{array}$ & $6.15 \pm 0.52$ & $3.23 \pm 0.69$ & $\begin{array}{l}7.98 \\
\pm 0.10\end{array}$ & $77 \pm 6.6$ & $13 \pm 1.0$ & $\begin{array}{l}233.67 \\
\pm 18.8\end{array}$ \\
\hline $\begin{array}{ll}\begin{array}{l}\text { Group } \\
(4 \mathrm{ml} / \mathrm{kg})\end{array} & 1\end{array}$ & $\begin{array}{l}44.33^{*} \\
\pm 0.22\end{array}$ & $\begin{array}{l}4.74 * \\
\pm 0.08\end{array}$ & $4.70 \pm 0.20$ & $\begin{array}{l}7.43 \\
\pm 0.25\end{array}$ & $\begin{array}{l}93.0^{*} \\
\pm 1.5\end{array}$ & $\begin{array}{l}15.5 \\
\pm 0.2\end{array}$ & $\begin{array}{l}342.17 * \\
\pm 19.3\end{array}$ \\
\hline $\begin{array}{l}\text { Group } \\
(6 \mathrm{ml} / \mathrm{kg})\end{array}$ & $\begin{array}{l}46.17 \\
\pm 0.87\end{array}$ & $\begin{array}{l}5.30 \\
\pm 0.10\end{array}$ & $\begin{array}{l}5.58^{+*} \\
\pm 0.34\end{array}$ & $\begin{array}{l}9.66^{+*} \\
\pm 0.15\end{array}$ & $\begin{array}{l}86.5^{+} \\
\pm 1.5\end{array}$ & $\begin{array}{l}18.0^{*} \\
\pm 0.4\end{array}$ & $\begin{array}{l}431.3^{+*} \\
\pm 13.87\end{array}$ \\
\hline
\end{tabular}

Values are presented as mean $\pm S E M, n=6$ animals per group; * Significantly different from control $(P<0.05),{ }^{+}$Significantly different from Group $1(P<0.05)$ 


\section{DISCUSSION}

Alterations in some haematological indices have been observed following oral gavaging of Bonny light crude oil to Guinea pigs. Several studies have shown that lipophilic hydrocarbons are absorbed with dietary fat across the intestinal tract of animals such as mallard ducklings (Anas platyrhynchos) and river otters (Lontra Canadensis $)^{22,23}$. Additionally, volatile lowmolecular weight components diffuse into the blood through the respiratory $\operatorname{tract}^{24}$. After absorption via the pulmonary or gastrointestinal routes, crude oil is transported in plasma initially bound to albumin and other larger proteins to the liver ${ }^{4}$.

Exposure of Guinea pigs to crude oil caused a significant reduction in red blood cell and haematocrit values. The observed reduction in red cell count in this study is in line with the study of Leighton et $a l^{25}$ who reported Heinz body formation and development of haemolytic anaemia in young herring gulls and Atlantic puffins five days after daily oral doses of a Prudhoe Bay crude oil. Similarly, decreased erythrocyte and platelet counts, and packed cell volume have been reported in rabbits exposed chronically to Nigerian crude oil ${ }^{26}$. The observed reduction in erythrocyte count may be attributed to the cytotoxic effects caused by compounds in crude oil. This could arise due to oxidative stress since crude oil is known to cause oxidative stress and increased membrane permeability in red cells ${ }^{25}$. Exposure or contact with chemicals in oil-refining industry have also been associated with changes in the red cell adenyl and blood monooxygenase system ${ }^{27-28}$. The observed decrease in packed cell volume corresponds with the decrease in red cell count ${ }^{29}$.

The values obtained for mean corpuscular volume (MCV) and mean corpuscular hemoglobin $(\mathrm{MCH})$ serve to indicate variations in erythrocyte shape, size and haemoglobin content. In this study there was an increase in $\mathrm{MCV}$ and $\mathrm{MCH}$. The increased $\mathrm{MCH}$ is in line with a previous study ${ }^{25}$ that reported that stained smears of red blood cells from nestling herring gulls that ingested Prudhoe crude oil were characterized by anisocytosis, poikilocytosis and reticulocytosis. Reticulocytes are larger in size than mature red blood cells, hence the increased MCV noted in this study could be attributed to the presence of larger number of reticulocytes in circulation than the mature red blood cells. However, it was noted that the haemoglobin concentration was significantly higher in the group II animals when compared with control. This elevation also reflects the higher value of $\mathrm{MCH}$ in this group when compared with control. The rise in haemoglobin despite the reduced red blood cell count is indicative of haemolytic anaemia $^{30}$. Crude oil is known to increase membrane permeability in red cells ${ }^{25}$ and reduce the osmotic resistance of red blood cells ${ }^{31}$ and this could lead to excessive haemolysis and release of haemoglobin. This may in part explain the increase in haemoglobin despite the decrease in red cell count.

The total white blood cell counts increased linearly with increased concentration of crude oil. The present result is contrary to the findings of Ovuru and Ekweozor ${ }^{26}$ who reported a reduction in total white blood cell counts in rabbits exposed to crude oil. This difference may be due to different experimental design and duration of exposure. The observed increase in white blood cells and platelets count could be attributed to acute response of the myeloid and megakaryotic stem cells to high dosage of the oil. Studies have shown that these stem cells have the selective advantage of proliferation and resistance to acute toxicity of crude oil and its metabolites ${ }^{16,32-33}$.

In conclusion, acute exposure of Guinea pigs to crude oil significantly decreased the red blood cell count and haematocrit while increasing the white blood cell and platelet counts. Bonny light crude oil causes haemolytic anaemia which is attributed to the toxic effects of various components of the oil.

\section{REFERENCES}

1. Edwards, C. W. (1989) Toxicology of oil field waste hazards to livestock associated with the petroleum industry. Vet. Clin. N. Amer. 5:363-374. 
2. Coppock, R. W., Mostrom, M. S., Khan, A., Semalula, S. S. (1995) Toxicology of oil field pollutants in cattle: A Review. Vet. Hum. Toxicol. 37:369-576.

3. Djomo, J. E., Ferrier, V., Gauthier, L., Zoll-Moreux, C. and marty, J. (1995) Amphibian micronucleus test in vivo: evaluation of the genotoxicity of some major polycyclic aromatic hydrocarbons found in a crude oil. Mutagenesis 10:223-226.

4. Orisakwe, O. E., Njan, A. A., Afonne, O. J., Akumka, D. D., Orish, V. N. and Udemezue, O. O. (2004) Investigation into the nephrotoxicity of Nigerian Bonny light crude oil in albino rats. Int. J. Environ. Res. Pub. Hlth. 1:106-110.

5. Volkman, J. K., Miller, G. J., Revill, A. T. and Connell, D. W. (1994) Oil spills. In: Environmental Implications of Offshore Oil and Gas Development in Australia - The Findings of an Independent Scientific Review (Swan, J. M., Neff, J. M. and Young, P. C. Eds) Australian Petroleium Exploration Association, Sydney. pp. $509-$ 695.

6. Njeze, C. C. (1983) The environmental impacts and implications of petroleum hydrocarbons in Nigeria. Environmental Focus 1:55-65.

7. Whitlock, J. P. and Gelboin, H. V. (1979) Aryle hydrocarbon (benzola)-pyrene) hydroxylase induction in cell culture. Pharm. Ther. 4:587-599.

8. Chet, I. and Michell, R. (1970) Petroleum hydrocarbons inhibit decomposition of organic matter in seawater Nature 261:308309.

9. Parker, P. L. Menzel, D. (1974) Effects of Pollution on Marine organisms, National Sciences Foundation IDOE, Washington D. C.

10. Krebs, C. T. and Burns, K. A. (1977) Long term effects of an oil spill on population of the salt marsh crab, Uca Prynax. Science 197:484-487.

11. Eyong, E. U. (2000) Biochemical and toxicological implications following ingestion of shellfish exposed to crude oil polluted water. Ph.D. Thesis, Department of Biochemistry, University of Calabar, Calabar, Nigeria. 329 pp.
12. Bochm, P. D. and Quinn, J. G. (1977) The Persistence of chronically accumulated hydrocarbons in the hardshell clam, Macenasia mercenaria, Mar. Biol. 44:227233.

13. Udoete, U. B. (1997) Toxicological evaluation of Qua Iboe crude oil in rats M.Sc. Thesis University of Calabar, Calabar - Nigeria. 178 pp.

14. Bus, J. S. (1985) Alkanes. In Bioactivation of Foreign Compounds, ed. M. W. Anders, Academic Press, Orlando Fla., pp. 111-120.

15. Thakker, D. R., Yagi, H., Liven, W., Wood, A. W., Conney, A. H., and Jernia, D. M. (1985) Polyaromatic hydrocarbons: Metabolic activation to ultimate carcinogens. In Bioactivation of foreign compounds, ed. M. W. Anders. Academic Press Orlando, Fla., pp 197-242.

16. Hedli, C. C., Ras, N. R., Reuhl, R. R., Witmer, R. S. (1996) Effects of benzene metabolite treatment on granulocytic differentiation and DNA adduct formation in HL-60 cells. Arch Toxicol. 70:135-144.

17. Chenna, A.; Harry, and Singer, B. D. (1997) Synthesis and site-specific incorporation of a benzene metabolite adduct, I. N-Benzoquinone - 2-deoxyguanosine into DNA oligonucleotides and its effects on replication and repair in vivo. Proc. Am. Assoc. Cancer Res. 38:464-469.

18. Martyn, T. S., Luoping, Z., Yunxia, W., Richard, B. H., Guilan, L., Joseph, W. M., Dosemeci, M. T. (1998) Increased translocation and aneusomy in chromosome 8 and 21 among workers exposed to benzene. Cancer Res. 5:2176-2181

19. Dacie, J. V. and Lewis, S. M. (1975) Practical Haematology, $5^{\text {th }}$ ed. Churchill Livingstone, London, pp. 502-503.

20. Alexander, R. R. and Grifiths, J. M. (1993a) Haematocrit. In: Basic Biochemical Methods. $2^{\text {nd }}$ ed., John Wiley and Sons Inc, New York, pp. $186-187$.

21. Alexander, R. R. and Grifiths, J. M. (1993b) Haemoglobin determination by the Cyanomethoemoglobin method. In: Basic Biochemical Methods. $2^{\text {nd }}$ ed., John Wiley and Sons Inc, New York, pp 188-189.

22. Eastin W. C. Jr, and Murray, H. C. (1981) Effects of crude oil ingestion on 
avian intestinal function. Can. J. Physiol. Pharmacol. 59:1063-1068.

23. Ormseth, O. A. and Ben-David, M. (2000) Ingestion of crude oil: effects on digesta retention times and nutrient uptake in captive river otters. J. Comp. Physiol [B]. 170:419-428.

24. Vetter, R. D., Carey, M. C. and Patton, J. S. (1985) Coassimilation of dietary fat and benzo-(a)-pyrene in the small intestine: An absorptive model using the killfish. J. Lipid Res. 26:428-434.

25. Leighton, F. A., Lee, Y. Z., Rahimtula, A. D., O'Brien, P. J. and Peakall, D. B. (1985) Biochemical and functional disturbances in red blood cells of herring gulls ingesting Prudhoe Bay crude oil. Toxicol. Appl. Pharmacol. 81:25-31.

26. Ovuru, S. S. and Ekweozor, I. K. E. (2004) Haematological changes associated with crude oil ingestion in experimental rabbits. Afr. J. Biotechnol. 3:346-348.

27. Shakirov, D. F. and Farkhutdinov, R. R. (2000) Identification of high-risk groups at the examination of workers engaged in oilrefining industry. Gig. Sanit. 15:33-36.

28. Zuk'karnaev, T. R., Shakirov, D. F. and Farkhutdinov, R. R. (1999) Occupational aspects of work conditions and assessment of several clinical-biochemical and chemiluminescence parameters in workers of oil processing industry. Med. Tr. Prom. Ekol. 7:28-33.

29. Eastham, R. D. and Slade, R. R. (1993) Clinical Hematology $7^{\text {th }}$ ed. Butterworth Heinemann Ltd. pp. 5-9, 83-105, 153-177.

30. Leigton, F. A. (1990) The systemic toxicity of Prudhoe Bay crude and other petroleum oil to CD-1 mice. Arch. Environ. Contam. Toxicol. 19:257-262.

31. Shakirov, D. F., Samsonov, V. M., Kudriavtsev, V. P. and Gil'manov, A. Z. H. (2003) Acid and osmotic erythrocyte resistance in workers at a petroleum factory. Klin Lab Diagn. 7:21-23.

32. Hayes, R. B., Yin, S. B., Li, C. Y., Rothman, N., Hoover, R. N. and Link, $M$. S. (1997) Benzene and dose - related incidence of hematolytic neoplasms in China Chinese Academy of Preventive Medicine National Cancer Institute, 89:1065-1071.

33. Russel, N. H. (1997) Biology of acute leukemia Lancet 349:118-122. 